\title{
Mata Ina: Upaya Pemberdayaan Komunitas Perempuan Leihari di Ambon: Perspektif Pendampingan dan Konseling Feminis
}

\author{
${ }^{1}$ Beatrix Rumahlatu, ${ }^{2}$ Jacob Daan Engel \\ ${ }^{1}$ Sosiologi Agama, Universitas Kristen Satya Wacana, Salatiga, Indonesia \\ E-mail: 752018037@ student.uksw.edu \\ ${ }^{2}$ Doktor Sosiologi Agama, Universitas Kristen Satya Wacana, Salatiga, Indonesia \\ E-mail: jopie_engel@yahoo.com
}

\begin{abstract}
Abstrak: Penelitian ini bertujuan untuk mengangkat nilai-nilai harkat dan martabat perempuan melalui upaya pemberdayaan dari perspektif pendampingan dan konseling feminis. Metode yang digunakan ialah metode penelitian kualitatif dan teknik wawancara terhadap perempuan dan tokoh-tokoh adat negeri Leihari. Berdasarkan data yang diperoleh, penulis menemukan nilai-nilai yang dapat dikembangkan sebagai upaya pendampingan dan konseling feminis yakni: kesadaran diri, penerimaan diri, komitmen diri dan makna hidup.
\end{abstract}

Kata kunci: Pendampingan; Konseling Feminis; Kesadaran diri; Penerimaan diri; Komitmen diri; Makna hidup.

\begin{abstract}
This article discusses Mata Ina as the social status of every woman especially Leihari - Ambon City. This status has been attached to women since birth so that women have a big role in traditional rituals carried out in the country of Leihari. This writing aims to elevate the values and dignity of women through empowerment from the perspective of feminist assistance and counseling. The method used is a qualitative research method and interview techniques with women and traditional leaders in the country of Leihari. Based on the data obtained, the authors found values that could be developed as an effort to assist and counsel feminist namely: self-awareness, self-acceptance, self-commitment and meaning of life.
\end{abstract}

Keyword: Mata Ina; Guidance; Counsel feminist; self-awareness; Self-acceptance; Self commitment; meaning of life.

\section{PENDAHULUAN}

Masyarakat Negeri Leihari merupakan masyarakat yang mendiami suatu desa pada kecamatan Leitimur selatan, Kota Ambon Maluku. Dalam konteks masyarakat Negeri Leihari yang menyimpan nilai-nilai budaya terdapat salah satu budaya yaitu; Mata Ina yang merupakan penghargaan terhadap kontribusi perempuan dalam masyarakat sehingga Mata Ina melekat dan menjadi status sosial pada setiap perempuan di Negeri Leihari sejak dilahirkan. Untuk itulah peran Ina di masyarakat Negeri Leihari tidak terlepas dari identitas diri perempuan. Kedudukan perempuan pada masyarakat Leihari dalam menjalankan peran dan tanggung jawabnya bukanlah menjadi orang kedua setelah laki-laki, melainkan sosok yang dengan sendirinya telah memelihara tradisi dan pusaka budaya. 
Penelitian terdahulu secara global telah membahas tentang konseling feminis oleh beberapa ahli antara lain (Sands, 1998) dalam risetnya tentang konseling yang ditujukan untuk mengatasi depresi pada perempuan. Hasil risetnya mengungkapkan bahwa strategi dalam konseling bagi perempuan merupakan perpaduan antara sensitivitas pemahaman gender dengan struktur sosial. Hal ini menandakan bahwa arah pendekatan konseling memfokuskan pada pentingnya hubungan interpersonal dengan dukungan konteks sosial budaya. Sehingga (Brown, 2006) menyatakan bahwa kekuatan konseling feminis adalah konseli diarahkan untuk membuat perubahan yang lebih baik pada diri dan lingkungannya. Berbeda dengan penelitian sebelumnya, penelitian ini akan menyoroti tentang nilai-nilai yang dapat dikembangkan sebagai upaya pendampingan dan konseling feminis dari budaya mata ina tersebut.

Selain itu dalam konteks Indonesia beberapa tahun terakhir ini, hasil penelitian terdahulu telah mengkaji tentang bagaimana peran perempuan terkait dengan konseling feminis (Noya, 2015) dalam penelitiannya dipaparkan single parent sebagai identitas kerap stereotipe oleh logika dominasi (masyarakat domain tertentu) yang kemudian mengintimidasi perempuan single parent sebagai perempuan yang gagal. Demikian halnya (Wattimena, 2015) dalam tulisannya tentang peran perempuan pasca perceraian dari perspektif konseling feminis dengan tujuan sebagi upaya pemberdayaan diri seorang perempuan dalam memahami bahwa peran tersebut haruslah dilihat sebagai kekuatan untuk memberdayakan. Selain melihat dari identitas perempuan-perempuan itu sendiri, persepektif konseling feminis pada kedua peneliti diatas dilihat sebagai kekuatan untuk memberdayakan perempuan.

Namun yang membedakan dengan penulisan ini adalah penulisan ini menggunakan perspektif pendampingan dan konseling feminis dalam konteks budaya (kearifan lokal). Perempuan dilihat sebagai fokus yang akan merangkul dan mengikat semua peran perempuan dari nilai-nilai budaya dalam pendampingan dan konseling feminis di Maluku. Sehingga dengan jelas akan nampak bagaimana perempuan-perempuan akan diberdayakan dari ketidakberdayaan bahkan masalah yang dialami. Perempuan yang dimaksud bukan hanya perempuan dalam lingkup gereja saja tetapi juga dari dalam masyarakat adat dan budaya kelompok tertentu. Hal yang lainnya juga bahwa ternyata ada nilai-nilai budaya di Ambon terkhususnya di Negeri Leihari yang menjunjung tinggi harkat dan martabat perempuan sehingga sebenarnya semua perempuan memiliki kekuatan untuk mengelola setiap problematik yang terjadi agar tidak dipandang lemah dan rendah. Pendampingan dan konseling feminis Mata Ina yang hendak dibangun berangkat dari konteks masyarakat Maluku dengan berbagai isu ketidakadilan sosial ini kiranya dapat menjawab kebutuhan kaum perempuan pada suatu kelompok atau daerah tertentu.

Makna dan arti dari kebudayaan menurut Seorang antropolog Inggris Edward B. Taylor (1832-1917) mengatakan bahwa kultur adalah keseluruhan yang kompleks termasuk didalamnya pengetahuan, kepercayaan, kesenian, moral, hukum adat dan segala kemampuan dan kebiasaan lain yang diperoleh manusia sebagai seorang anggota masyarakat (Francis, 1958). Dengan demikian, budaya mengandung nilainilai yang kemudian dijaga oleh masyarakat itu sendiri. Bagi masyarakat Negeri Leihari dalam budaya Mata Ina, perempuan memiliki hak untuk menjaga budaya tersebut karena secara leluhur, perempuan dipercayakan untuk menjaga, menyimpan dan melestarikan segala sesuatu.

Adapun aktivitas yang dilakukan oleh komunitas Mata Ina dalam negeri ini adalah terlibat dalam penjemputan tamu-tamu penting pada ritual adat negeri, sebagai pemegang kain gandong (kain saudara) dan mengurus konsumsi pada acara-acara yang dilaksanakan di Negeri Leihari. Untuk itulah, perempuan memiliki peranan yang juga penting dalam berbagai prosesi adat Negeri. Tanpa perempuan prosesi adat tidak akan terlaksana. Namun disisi lain, status mata ina tidak berlaku bagi perempuan yang hamil diluar pernikahan, mereka akan disebut "bukan mata ina" dan tidak diperkenankan lagi untuk terlibat langsung dalam prosesi adat, mereka tidak boleh berada di depan dan tidak diberi peran serta tanggung jawab penting seperti kaum perempuan lainnya di Negeri Leihari. Hal ini menimbulkan rasa tidak percaya pada diri perempuan yang mengalami masalah tersebut. Secara tidak langsung perempuan Bukan Mata Ina akan menarik diri dari masyarakat dan menutup dirinya terhadap orang lain.

Tujuan penulisan ini untuk menghadirkan pendampingan dan konseling feminis bagi perempuan Mata Ina bahwa perempuan sebagai sumber kehidupan (yang melahirkan kehidupan) dan memeliharanya 
sebagai perempuan yang mampu mengelola konflik secara baik. Dalam hubungan pendampingan dan konseling feminis yang berpusat pada upaya pemberdayaan pada perempuan, konseling feminis pada hakikatnya bagi setiap perempuan yang mengalami ketertindasan, ketidakadilan dan diskriminasi sehingga memojokan dan mengucilkan perempuan. Untuk itu, pendampingan dan konseling diperlukan dalam rangka pemulihan dan pemberdayaan konseli yang teralienasi.

\section{METODE}

Metode penelitian yang digunakan adalah metode penelitian kualitatif dengan jenis penelitian deskritif. Jenis dan metode penelitian kualitatif digunakan untuk memperoleh data yang mendalam berdasarkan pemahamanpemahaman para informan (Creswell, 2010).

Penelitian ini dilakukan di Negeri Leihari, Ambon - Maluku. dalam penelitian ini, Teknik pengumpulan data yang akan dipergunakan dalam penelitian ini, yakni wawancara. Wawancara adalah pertemuan antar dua orang untuk bertukar informasi dan ide melalui tanya jawab, untuk mengkostruksikan makna dalam suatu topik tertentu secara mendalam, tentang partisipan dalam menginterpretasikan situasi dan fenomena yang terjadi. Jenis wawancara yang digunakan yaitu wawancara face to face yang dilakukan dengan tujuan untuk memperoleh data secara langsung dari tangan pertama. Jenis-jenis pertanyaan dalam wawancara saling berkaitan, antara lain: tentang pengalaman, perasaan, pendapat, dan pengetahuan (Sugiyono, 2013). Selain itu, kajian literatur digunakan guna memperoleh landasan teori dari buku. Subjek penelitian yang akan diwawancarai ialah tokoh adat (para saniri negeri/badan pemerintah negeri) dan tokoh perempuan di Leihari (Mata Ina).

\section{HASIL DAN PEMBAHASAN}

\section{Mata Ina dalam budaya masyarakat Leihari}

Setiap budaya memiliki pemahaman tersendiri tentang perempuan. Dalam budaya Maluku, salah satunya "MATA INA". Secara filosofis, Mata artinya "asal" atau "induk" dan Ina merupakan sapaan halus bagi seorang ibu atau seorang perempuan sehingga Mata Ina dapat diartikan sebagai asal atau induk perempuan. Dapat dikatakan juga Mata Ina sebagai simbol dari perempuan dan karena itu, budaya Mata Ina sangat melekat pada diri atau identitas perempuan.

Secara filosifis, Ina atau Inai yang merupakan sapaan halus bagi seorang ibu atau seorang perempuan yang menunjukan sosok dalam pengertian terfokus atas suatu kerangka pikir yang terstruktur secara natalis embrio (kandungan kelahiran), social identitas (identitas sosial), privalase identitas (penghargaan identitas) dan geografis identitas (identitas wilayah kelahiran) (Pattipeilohy, 2017). Sebutan Ina juga bermula dari narasi mitos Nunusaku dan Nusa Ina sebagai mitos asal leluhur Maluku Tengah. Mitos tersebut menggambarkan hubungan persaudaraan dengan menjadikan Nunusaku sebagai pusat bersama dan Ina sebagai ibu bersama. Nilai-nilai persaudaran dan keibuan yang dimiliki sangat berguna dan masih relevan hingga saat ini di Maluku. Ada banyak simbol yang dapat ditemukan dalam diri seorang Ina di Maluku. Ina digambarkan sebagai sumber kelahiran yang dapat memberikan kehidupan baru dan terus bertumbuh untuk memenuhi bumi Maluku. Oleh sebab itu, Ina dapat disimbolkan sebagai air susu yang menghidupkan anak-anak di Maluku. Dengan demikian, sosok Ina dapat menjadi titik terang yang memberi cahaya kehidupan bagi masyarakat di Maluku (Tiwery, 2015).

Hal pertama yang dikemukakan oleh Pattipeilohy, bahwa Ina sebagai bejana kehidupan menggambarkan sosok Ina yang memiliki rahim dan yang dapat melahirkan seorang manusia. Itu berarti bahwa Ina dapat memberi suatu kehidupan melalui kandungannya. Ina identik dengan rahim, sebagai penampung embrio yang dijaga, dipelihara sampai dengan proses melahirkan. Oleh sebab itu, masyarakat Maluku memahami bahwa tubuh atau rahim Ina adalah bagian yang suci, sakral, sebagai rumah tempat berlindung dan secara primordial, harus diakui bahwa peran yang dijalankan Ina sebagai rahim kehidupan dapat melahirkan sebuah generasi.

Berdasarkan pemahaman masyarakat Negeri Leihari bahwa kaum perempuan memiliki posisi penting dalam kebudayaan Leihari, maka dari itu Mata Ina sendiri merupakan proyek identitas yang menunjukan bahwa dalam kebudayaan mereka memiliki tanggung jawab terhadap berbagai prosesi adat masyarakat setempat dan disebut dengan "Mata Ina" atau "Mata Ibu".

Berdasarkan kodratnya, pembagian peran dan tugas antara laki-laki dan perempuan 
dalam kehidupan sosial masyarakat Maluku telah ada sejak masa lampau. Sehingga perempuan dalam konteks menjalankan peran dan tanggung jawabnya bukan menjadi orang kedua sesudah laki-laki, melainkan sosok yang dengan sendirinya telah memelihara tradisi dan pusaka budaya. Perempuanlah yang telah menghidupkan tradisi dalam pusaka-pusaka budaya bahkan itu sudah dimulai dari peran, tugas dan tanggung jawabnya dalam keluarga.

Disisi lain, kenyataannya perempuan mengalami sanksi sosio cultural di negeri Leihari, status Mata ina tidak berlaku bagi perempuan yang hamil diluar pernikahan, mereka akan disebut "Bukan Mata Ina" dan tidak diperkenankan lagi untuk terlibat langsung dalam prosesi adat, mereka tidak boleh berada di depan dan tidak diberi peran serta tanggung jawab penting seperti kaum perempuan lainnya di Negeri Leihari. Status seorang perempuan yang "bukan Mata Ina", dapat berubah kembali menjadi Mata Ina hanya ketika dia menikah. Meskipun jika nantinya perempuan tersebut bercerai dengan suaminya, dia tetap menyandang status tersebut.

\section{Mata ina sebagai upaya pemberdayaan komunitas perempuan Leihari di Ambon}

Konseling feminis berkaitan dengan pemberdayaan perempuan (Rungreangkulkij, 2013). Salah satu aspeknya yakni; berfokus pada pemberdayaan kesadaran kepercayaan diri untuk meyakini nilai mereka sendiri, sehingga mereka dapat membuat keputusan dan mengontrol kehidupan mereka. Sehingga proses pemberdayaan ini dapat membantu perempuan untuk memilih dan mengontrol jalur hidup mereka. Dengan demikian, perempuan mampu mengembangkan proses pemberdayaan melalui kesadaran kritis (Engel, 2016).

$$
\text { Upaya pemberdayaan komunitas }
$$

perempuan Negeri Leihari (Mata Ina) berdasarkan hasil wawancara dalam mengelola konflik melahirkan nilai-nilai yang menghidupkan dan dapat dikembangkan dalam pendampingan dan konseling feminis yakni kesadaran diri (self-awareness), penerimaan diri (self-acceptance), komitmen diri (self commitment) dan makna hidup (meaning of life).

1. Kesadaran diri (self-awareness)

Ketika orang-orang terlibat dalam sebuah konflik, mereka akan menarik diri karena merasa terluka. Biasanya di dalam diri mereka akan berkembang sebuah kesadaran diri yang baru. Kesadaran baru bahwa mereka ternyata adalah makhluk yang rentan, makhluk yang bisa terluka. Mereka ternyata tidaklah setangguh dan sekuat sebagaimana yang mereka pahami sebelum konflik (Widjaja, 2016). Oleh karena itu, dalam upaya menyadari keterlukaan, kesadaran diri menjadi sebuah upaya pemberdayaan untuk suatu perubahan sikap dan perilaku sehat (Engel, 2014).

Dalam sebuah ritual yang terlaksana di Negeri Leihari, perempuan-perempuan yang tidak menyandang status Mata Ina dengan sendirinya menyadari keberadaan diri mereka dengan tidak terlibat dalam ritual tersebut. Tidak dapat dipaksakan untuk mereka bisa terlibat dalam ritual adat yang dilaksanakan karena sesuai aturan adat jika mereka dilibatkan maka akan terjadi hal-hal diluar kelancaran dari ritual yang berlangsung. Oleh karena itu, tanpa dikatakan oleh tokoh adatpun perempuan bukan Mata Ina telah dengan sendirinya menyadari posisi mereka di dalam masyarakat.

Dibalik ketidakterlibatan yang dipandang sebagai kelemahan setiap individu, kesadaran diri dapat menjadi kekuatan sebagai upaya pemberdayaan suatu perilaku seseorang. Dari situasi yang dihadapi baik tantangan dan masalah, individu mampu menerima dengan penuh kesabaran dan katabahan dan juga keberanian untuk menghadapinya sehingga dapat membuka peluang besar untuk menemukan makna hidup. Dengan bangkitnya kesadaran diri yang dalam, seseorang dapat menyesuaikan dirinya dengan keadaan, mengintropeksi, membuka diri serta mengembangkan kepercayaan diri untuk penemuan makna hidup. Hidup setiap manusia tentunya memiliki makna bahkan dalam kondisi yang menyakitkan seseorang mampu untuk mengubah hidupnya dari yang negatif ke sesuatu yang positif dan konstruktif.

Dengan demikian, upaya pemberdayaan tersebut berhubungan dengan kemampuan untuk membuat keputusan dan mengatasi masalah karena kesadaran diri merupakan fundamen utama suatu pengendalian diri setiap individu yang mengalami harga diri spiritual yang rendah.

\section{Penerimaan diri (self acceptance)}

Penerimaan diri sebagai sebuah kekuatan bahwa setiap orang memiliki kesadaran, mengakui perilaku dan tidak lagi takut untuk mengenali kekurangan diriya. Mengenali diri sendiri memberi kemungkinan seseorang untuk memperbaiki kehidupan dirinya sendiri dengan berhenti membandingkan dirinya dengan orang 
lain. Dengan demikian, penerimaan diri artinya menerima kekurangan dan prestasi sebagai kekuatan untuk mengatasi masalah hidup (Engel, 2014). Penerimaan diri memiliki peran yang penting dalam sebuah interaksi sosial. Dalam kenyataan, seseorang sulit menerima orang lain akan mempengaruhi aktualisasi dirinya sendiri. Untuk itu penerimaan diri baik agar individu dapat menyadari dirinya, apa yang menjadi kelemahan ataupun kelebihannya yang bisa digunakan dalam menghadapi masalah yang dihadapi dan tuntutannya dalam menjalankan peran di masyarakat.

Merasa ditolak dari keberadaan masyarakat adalah hal yang dianggap tidak baik dan tidak nyaman. Itulah yang dirasakan oleh perempuan bukan mata ina yang menyadari diri mereka berbeda dengan orang lain. Namun, penerimaan diri dapat dijadikan sebagai kekuatan pendampingan dan konseling feminis. Dengan penerimaan diri perempuan bukan Mata Ina didorong untuk menyadari keberadaan dirinya dengan penuh kesadaran dan mau melihat fakta yang ada pada diri, baik fisik maupun psikis sekaligus kekurangan dan ketidaksempurnaan tanpa ada kekecewaan tujuannya untuk merubah diri menjadi lebih baik.

\section{Komitmen diri (self commitment)}

Dalam menghadapi sebuah masalah, individu sering menyalahkan diri sendiri dan mengkritik dirinya bahkan menyesali apa yang terjadi pada dirinya. Mereka merasa tidak berharga sehingga menimbulkan keyakinan negatif terhadap diri mereka sendiri. Mereka merasa tertekan, merasa sedih dan putus asa. Demikian halnya yang dirasakan oleh perempuan bukan Mata Ina masyarakat Negeri Leihari. Upaya pemberdayaan perempuan hadir untuk menyadari kesadaran dan pengambilan keputusan, membuat kebijakan-kebijakan self -nurturance (peduli diri) dan menjadikan perempuan seperti mendapat kekuatan baru untuk melanjutkan hidupnya yang bertujuan dan bermakna.

Perempuan bukan Mata Ina perlu menyadari bahwa komitmen tidak akan pernah terwujud jika proses pengampunan pada diri sendiri diabaikan. Oleh karena itu, sebelum melangkah ke tahap pemaknaan hidup, individu mestinya memiliki komitmen dalam diri sebagai suatu kemampuan dan motivasi diri berupa dorongan yang menggerakan seseorang untuk bertingkah laku. Motivasi ini yang menjadi kekuatan individu untuk mencapai tujuan tertentu. Dengan demikian, motivasi menjadi pendorong seseorang memiliki komitmen diri untuk keluar dari keterpurukan dan berani melewati masalah untuk perubahan yang lebih baik. Dengan mengingat tujuan hidup sebagai seperangkat nilai keikatan diri (self commitment) dalam melakukan berbagai kegiatan nyata yang lebih terarah guna mencapai makna dan tujuan hidupnya (Engel, 2014).

\section{Makna hidup (meaning of life)}

Konseling merupakan suatu upaya untuk memanusiakan sesama manusia. Dalam upaya memanusiakan itulah terkandung makna pemberdayaan (Engel, 2018). Sehingga seseorang dapat menemukan makna hidup (meaning of life) karena makna hidup sangat penting dan berharga serta memberikan nilai khusus bagi seseorang dan layak dijadikan tujuan dalam kehidupannya (Engel, 2014). Kehidupan yang bermakna akan dimiliki seseorang jika mengetahui apa makna dari sebuah pilihan hidup. Makna hidup bermula dari sebuah visi kehidupan, harapan hidup dan alasan mengapa seseorang harus terus hidup. Kebermaknaan ini adalah kekuatan yang mendorong seseorang untuk memiliki komitmen hidup dan menjadikan seseorang berguna tidak hanya untuk diri sendiri tetapi juga untuk orang lain.

Makna hidup merupakan hal pribadi yang dapat berubah-ubah seiring berjalannya waktu dan perubahan situasi dalam kehidupan individu. Makna hidup memang tidak mudah ditemukan dalam kehidupan seorang individu akan tetapi makna hidup benar-benar ada dalam kehidupan (Frankl, 2006). Apabila makna hidup berhasil ditemukan dalam kehidupan maka kehidupan akan terasa lebih berarti dan berharga yang dapat melahirkan kebahagiaan. Kebahagiaan itulah yang menjadi pencapaian makna hidup seseorang.

Status bukan Mata Ina bukanlah penghalang seseorang untuk hidup namun menjadi kekuatan seseorang bisa hidup berdamai dengan diri sendiri dan bermakna bagi orang lain. Melalui proses dan pencapaian-pencapaian sebagai upaya pemberdayaan semua perempuan. Perempuan bukan lagi dilihat sebagai korban dari ketidakadilan namun sebagai sosok yang dianugrahi hati dan rasa yang peka menawarkan nilai-nilai kehidupan sebagai suatu alternatif dalam proses rekonsiliasi.

Dengan demikian, setiap pribadi maupun individu diharapkan agar dapat menyadari bahwa dirinya memiliki nilai-nilai yang dapat 
diterapkan berdampak positif mengurangi kecemasan dan ketakutan sehingga adanya perubahan ke arah yang lebih baik dengan tujuan dan makna hidup yang jelas sehingga terjadi transfer of meaning bagi hidupnya.

\section{Teori Pendampingan dan Konseling Feminis}

Pendampingan merupakan suatu jawaban terhadap kebutuhan setiap orang akan kehangatan, perhatian penuh dan dukungan (Howard, 2011). Kebutuhan ini memuncak pada waktu tekanan pribadi dan kekacauan sosial terjadi (Clinebell, 2002). Sama halnya pendampingan menurut Engel sebagai kegiatan menolong dengan memiliki arti kegiatan kemitraan, bahu membahu, menemani, berbagi dengan tujuan saling menumbuhkan dan mengutuhkan (Engel, 2016).

Selain itu, pendampingan dan konseling menurut Engel sebagai suatu panggilan yang dilakukan oleh setiap orang dalam merespon panggilan Allah. Pendampingan dan konseling bukan saja menjadi tanggung jawab seorang pendeta, pastor atau kaum rohaniwan tetapi semua orang percaya yang terpanggil untuk melaksanakan tugas penggembalaan itu. Signifikansi pendampingan dan konseling secara konseptual dari segi fungsi, keduanya menjalankan fungsi yang sama, untuk membimbing, menopang, memperbaiki, memberdayakan, memulihkan dan menyembuhkan (Clinebell, 2002).

Pendampingan dalam upaya menyembuhkan dan membalut luka orang lain mencakup sebuah pelayanan suatu komunitas sepanjang hidupnya. Pendampingan dapat berlanjut menjadi konseling apabila diperlengkapi lagi dengan ketrampilan dan pelatihan umtuk meningkatkan kemampuan dan bakat dalam mengatasi masalah-masalah atau krisis-krisis yang lebih kompleks. Dengan demikian, orang membutuhkan pendampingan sepanjang hidupnya, tetapi mungkin orang membutuhkan konseling ketika mengalami krisis yang hebat (Clinebell, 2002).

Istilah konseling dari bahasa inggris to counsel secara harafiah berarti memberi arahan, nasihat. Konseling juga diartikan sebagai proses pertolongan antara seorang penolong (konselor) dan yang ditolong (konseli-klien) dengan maksud untuk meringankan penderitaan konseli/klien (Vaan Beek, 2017). Pengertian yang lain, konseling merupakan suatu upaya untuk memanusiakan sesama manusia. Dalam upaya memanusiakan itulah terkandung makna pemberdayaan (Engel, 2018) sehingga seseorang dapat menemukan makna hidup (meaning of life) karena makna hidup sangat penting dan berharga serta memberikan nilai khusus bagi seseorang dan layak dijadikan tujuan dalam kehidupannya (Engel, 2014). Itu berarti bahwa konseling tidak hanya sekedar membawa orang keluar dari keterpurukan dan penderitaan hidup tetapi mengembangkan potensi - potensi yang dimiliki untuk memberdayakan dirinya dan orang lain bahkan masyarakat.

Konseling feminis juga merupakan kepekaan terhadap masalah-masalah perempuan yang kerap terjadi dalam berbagai aspek kehidupan. Tujuan konseling feminis ialah sebagai pemberdayaan perempuan dalam menerapkan perubahan serta kesadaran dalam dirinya serta memahami bahwa dirinya masih merupakan kepribadian yang utuh. Berkaitan dengan itu, perspektif konseling feminis haruslah dilihat sebagai kekuatan untuk memberdayakan. Dengan demikian, konseling feminis menjadi sebuah solusi alternatif merangkul, mempertemukan dan pendampingan bagi perempuan maluku agar perempuan sebagai Mata Ina selain dapat menemukan makna hidupnya (The meaning of life) tetapi juga berani menjadikan dirinya untuk hidup bermakna bagi orang lain (the will to meaning) (Bastaman, 2007).

\section{Pendampingan dan konseling feminis berbasis budaya terhadap upaya pemberdayaan komunitas perempuan leihari di Ambon}

Budaya merupakan bagian yang tak terpisahkan dari kehidupan manusia. Berkaitan dengan itu, kebutuhan konseling budaya di Indonesia sangat diperlukan mengingat Indonesia terdiri dari berbagai latar belakang yang berbedabeda. Oleh karena itu penulisan budaya mata ina sebagai upaya pemberdayaan perempuan dari perspektif pendampingan dan konseling feminis menjadi menarik ketika budaya menjadi pusat perhatian. Fokus utamanya adalah nilai-nilai yang ditemui pada perempuan bukan Mata Ina yang kemudian dikembangkan sebagai jawaban terhadap masalah perempuan yang mengalami sanksi sosio cultural, ketidakadilan dan ketertindasan. Dalam konseling feminis ini, penemuan dan pemahaman terhadap akar budaya menjadi sangat penting. Sehingga dengan cara ini, ada cara pandang yang unik dilahirkan dari setiap budaya menjadi suatu model yang baru.

Upaya pemberdayaan sebagai tujuan konseling merupakan cara untuk menghargai 
perbedaan, berusaha melakukan perubahan, kesetaraan, menyeimbangkan independensi dan interdependensi, perubahan sosial dan selfnurturance (peduli diri) (Whalen, 2004) berkaitan dengan hal itu, upaya pemberdayaan juga dapat mengubah kesadaran perempuan tentang kemampuan dirinya sebagai pribadi dan dalam mengisi peran sosialnya (Sadli, 2010). Dengan demikian, Mata Ina dalam perspektif pendampingan dan konseling feminis merupakan tujuan jangka panjang konseling yang dengan diberdayakan maka individu mampu membebaskan dirinya sendiri dari ikatan-ikatan para gender serta dapat menantang tekanantekanan institusional atas dirinya (Engel, 2016).

Kecenderungan saat ini semakin meningkat oleh kasus perlakuan sewenangwenang dan kekerasan terhadap perempuan baik secara fisik maupun psikis di Maluku sebagaimana terlihat di media elektronik maupun pemberitaan media masa bahwa keberadaan perempuan sangat memprihatinkan karena angka kekerasan terus meningkat. Rata-rata korban kekerasan dan ketidakadilan adalah perempuan. Pendampingan yang dihadirkan dalam penulisan ini akan membantu perempuan untuk menyadari bahwa terlahir sebagai perempuan adalah anugrah terindah dengan sebutan Ina (perempuan, ibu) dalam konteks orang maluku adalah pemberi semangat kehidupan. Dalam hal ini, Ina dapat mendampingi, merangkul, memberikan dan menanamkan nilai-nilai persaudaraan kepada anak-anaknya. Oleh sebab itu, Ina menjadi simbol solidaritas dan penghubung yang menghidupkan identitasidentitas masyarakat Maluku. Sejalan dengan hal itu, perempuan bukan Mata Ina dalam konteks masyarakat Negeri Leihari memaknai fungsi Ina dalam mendampingi, merangkul, menanamkan serta menanamkan nilai-nilai persaudaraan bagi perempuan bukan Mata Ina sebagai pemberi semangat dan motivasi untuk mereka bisa bangkit dari keterpurukan yang dialami. Demikian proses pendampingan yang dilakukan oleh perempuan komunitas Negeri Leihari dan yang menjadi gambaran besar bukan hanya kepada masyarakat Negeri Leihari namun kepada semua perempuan.

Proses konseling feminis dalam konteks masyarakat Negeri Leihari dalam melihat status seorang perempuan bukan Mata Ina akan menjadi Mata Ina ketika perempuan itu menikah lagi (memiliki suami). Setelah melewati proses sanksi sosial cultural oleh masyarakat, nilai kesadaran diri, penerimaan diri, komitmen diri dan makna hidup dijadikan sebagai kemampuan untuk memperoleh harga diri spiritual yang baik dan sehat. Sasaran pencapaian pembuktian individu dalam merealisasikan dan menemukan makna serta tujuan hidup di balik penderitaan hidup dan pengalaman pahit yang dialami menjadikan perempuan bukan Mata Ina untuk menghargai hidup sebagai suatu karunia yang tidak boleh disia-siakan.

Penulis melihat nilai-nilai budaya dari Mata Ina sangat membantu perempuan dalam proses pendampingan konseling, ketika perempuan Mata Ina mendapat sanksi sosial cultural maka pencarian perempuan mengenai makna merupakan kekuatan utama untuk mampu hidup dan melewatinya.

\section{SIMPULAN DAN SARAN}

Berdasarkan tujuan dan hasil pembahasan, kesimpulan dari penulisan ini adalah Mata Ina dalam komunitas perempuan Negeri Leihari dapat dikembangkan dengan perspektif pendampingan dan konseling feminis sebagai upaya pemberdayaan melawan sanksi sosio cultural dan mengangkat nilai dan martabat perempuan sehingga perempuan tidak dipandang sebelah mata oleh karna sanksi sosio cultural tersebut.

Pendampingan dan konseling feminis yang berbasis budaya dapat membantu dan mendampingi setiap individu atau kelompok dalam menyikapi setiap konflik dengan nilainilai yang terkandung di dalamnya. Dengan mengakat nilai kearifan lokal yang ada di Indonesia sebagai sebuah pendekatan pendampingan dan konseling maka secara tidak langsung setiap komunitas adat dapat mengaktualisasikan kehidupan mereka berdasarkan apa yang mereka anut bersama sehingga dapat menjawab kebutuhan kaum perempuan di suatu komunitas atau daerah tertentu.

Saran yang dapat disampaikan yaitu: Pertama, setiap komunitas di Indonesia dapat menggunakan nilai tradisi dan budaya yang dimiliki untuk membantu orang lain yang selanjutnya dapat digunakan sebagai bentuk pendekatan pendampingan dan konseling dalam mengatasi masalah sosial masyarakat. Kedua, Nilai dan budaya yang ada dalam masyarakat dapat dikembangkan untuk memberdayakan warga masyarakat menjadi manusia yang berdaya dan mampu menjalani kehidupannya ditengah permasalahan hidup yang dialami serta dapat menemukan meaning of life. Ketiga, 
8 | JURKAM: Jurnal Konseling Andi Matappa Vol 4, No 1, Februari 2020

Pendampingan dan konseling feminis berbasis budaya yang dibangun dalam masyarakat Indonesia yang majemuk dapat mengkaji akan falsafah bahkan nilai-nilai hidup dalam kearifan lokal budaya bangsa indonesia menjadi suatu teori konseling feminis yang kontekstual dan berpusat pada budaya serta dapat memanfaatkan nilai-nilai tersebut dalam ritual-ritual adat yang dijalankan untuk penyelesaian masalah.

\section{DAFTAR RUJUKAN}

Bastaman, H. D. (2007). LOGOTERAPI: Psikologi untuk menemukan makna hidup dan meraih hidup bermakna. Jakarta: PT Rajagrafindo Persada.

Brown, B. (2006). Feminist therapy. USA: American Psychological Association.

Clinebell, H. (2002). Tipe-tipe dasar pendampingan dan konseling pastoral. $\quad$ Yogyakarta: $\quad$ PT KANISIUS.

Creswell, J. W. (2010). Research design: Pendekatan Kualitatif, Juantitatif dan Mixed. Yogyakarta: Pustaka Pelajar.

Engel, J. D. (2018). Konseling Masalah Masyarakat. Yogyakarta: PT KANISIUS.

Engel, J. D. (2016). Konseling Pastoral dan Isuisu kontemporer. Jakarta: BPK Gunung Mulia.

Engel, J. D. (2014). Nilai Dasar Logo Konseling. Yogyakarta: PT Kanisius.

Engel, J. D. (2016). Pastoral dan Kebutuhan Dasar Konseling. Jakarta: BPK Gunung Mulia.

Francis, M. E. (1958). Society \& Culture an Introduction to Sosiology (Third edition ed.).

Frankl, V. E. (2006). LOGOTERAPI: Terapi Psikologi Melalui Pemaknaan Eksistensi. Yogyakarta: Kreasi Wacana.

Howard, R. A. (2011). Concepts and Controversies in Grief and Loss. Journalof Mental Health Counseling , Vol. 33, No 01, 4.
Noya, H. (2015). Peran single parent terhadap anak dari perspektif konseling feminis. UKSW, Pascasarjana Magister Sosisologi Agama. Salatiga: Tesis tidak diterbitkan.

Pattipeilohy, M. M. (2017, September 14). INA: Perempuan Maluku dalam Bejana kehidupan. Retrieved from https://kebudayaan.kemdikbud.go.id/ bpnbmaluku/ina-perempuan-malukudalam-bejana-kehidupan/.

Rungreangkulkij, T. \&. (2013). The effectiveness of Postmodern Feminist Empowering Counseling for Abused Woman: A Perspectives of Thai Abused Woman. International Journal of Behavioral Science, Vol. 8, No 1.

Sadli, S. (2010). Berbeda tetapi Setara: Pemikiran tentang kajian Perempuan . Jakarta: PT Kompas Media Nusantara.

Sands, T. (1998). Feminist counseling an female adolescents: Treatment strategies for depression. Journal of Mental Health Counseling , 20 (1), 42-54.

Sugiyono. (2013). Metode Penelitian Kuantitatif dan $R \& D$. Bandung: Alfabeta.

Tiwery, J. W. (2015). TEOLOGI INA: Terlahir dari rahim Maluku. Jakarta: BPK Gunung Mulia.

Vaan Beek, A. (2017). Pendampingan Pastoral. Jakarta: BPK Gunung Mulia.

Wattimena, J. (2015). Peran perempuan pasca perceraian perspektif konseling feminis. UKSW, Pascasarjana Magister Sosiologi Agama. Salatiga: Tesis tidak diterbitkan.

Whalen, M. \&. (2004). Counseling Practice With Feminist Multicultural Perspectives. Journal of Multicultural Counseling and Development, Vol. 32, 379-389.

Widjaja, P. S. (2016). Perempuan, Konflik \& Rekonsiliasi: Perspektif Teologi dan Praksis. Jakarta: BPK Gunung Mulia. 